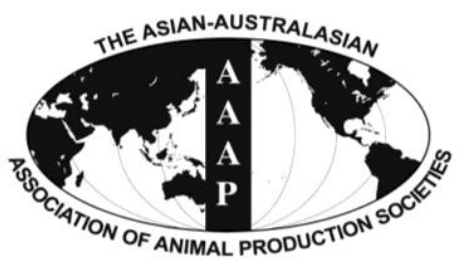

Asian Australas. J. Anim. Sci.

Vol. 26, No. 10 : 1359-1364 October 2013

http://dx.doi.org/10.5713/ajas.2013.13248

www.ajas.info

pISSN 1011-2367 elSSN 1976-5517

\title{
Identification of Single Nucleotide Polymorphisms (SNPs) of the Bovine Growth Hormone (bGH) Gene Associated with Growth and Carcass Traits in Hanwoo
}

\author{
Ji-Hong Lee ${ }^{\text {a }}$, Yun-Mi Lee ${ }^{1, a}$, Jea-Young Lee ${ }^{2}$, Dong-Yep $\mathrm{Oh}^{3}$, Dae-Jin Jeong ${ }^{3}$, and Jong-Joo Kim ${ }^{1 * *}$ \\ Gyeongbuk Provincial College, Yecheon, Gyeongbuk, Korea
}

\begin{abstract}
The purpose of this study was to find any association of the bovine growth hormone (bGH) gene with growth and carcass quality traits in Korean native cattle, Hanwoo. Genomic DNA was extracted from 21 Hanwoo individuals, and the 47 to 2,528 bp region of the $b G H 2,856 \mathrm{bp}$ (GenBank accession number M57764) including the promoter and the five exons was sequenced. A total of ten $b G H$ SNPs were confirmed, including four $(253 \mathrm{C}>\mathrm{T}, 303 \mathrm{C}>\mathrm{T}, 502 \mathrm{C}>\mathrm{T}$, and $559 \mathrm{G}>\mathrm{A})$ in the promoter, one $(679 \mathrm{C}>\mathrm{T})$ in exon 1, one $(1,692 \mathrm{~T}>\mathrm{C})$ in intron 3, and four $(2141 \mathrm{C}>\mathrm{G}, 2258 \mathrm{C}>\mathrm{T}, 2277 \mathrm{C}>\mathrm{T}$, and $2291 \mathrm{~A}>\mathrm{C})$ in exon 5. The ten $b G H$ SNPs were genotyped for a sample of 242 Hanwoo steers and association tests were performed to find any significant SNP that was correlated with growth and carcass quality. Of the SNPs, the $303 \mathrm{C}>\mathrm{T}$ SNP in the promoter region was significantly associated with 6-month-old weight, the $559 \mathrm{G}>\mathrm{A}$ SNP with longissimus dorsi muscle area, the $2141 \mathrm{C}>\mathrm{G}$ SNP in exon 5 with daily weight gain, and the $2258 \mathrm{C}>\mathrm{T}$ SNP with daily weight gain and carcass weight $(\mathrm{p}<0.05)$. The significant SNPs need to be verified in other Hanwoo populations before considering implementation of marker-assisted selection for genetic improvement of growth and carcass quality in Hanwoo. (Key Words: Bovine Growth Hormone Gene, Growth and Carcass Traits, Hanwoo, SNP)
\end{abstract}

\section{INTRODUCTION}

The bovine growth hormone $(b G H)$ gene is located in q22 of bovine chromosome 19 and includes five exons with 217 amino acids (Santome et al., 1971; Wallis, 1973; Miller et al., 1980). The gene was sequenced by Gordon et al. (1983) and Hediger et al. (1990). Its product, growth hormone, is secreted in somatotropic or acidophilic cells of the anterior pituitary gland of mammals. The hormone regulates expression of many genes including one encoding insulin-like growth factor I (IGF-I), and influences growth rate, body composition, health, and milk production (Woychik et al., 1982; Gordon et al., 1983; Sumantran et al.,

\footnotetext{
* Corresponding Author: Jong-Joo Kim. Tel: +82-53-810-3027, Fax: +82-53-801-3027, E-mail: kimjj@ynu.ac.kr

1 School of Biotechnology, Yeungnam University, Gyeongsan, Gyeongbuk, Korea.

${ }^{2}$ Department of Statistics, Yeungnam University, Gyeongsan, Gyeongbuk, Korea.

${ }^{3}$ Gyeongbuk Livestock Research institution, Yeongju, Gyeongbuk, Korea.

${ }^{a}$ The two authors contributed equally.

Submitted May 7, 2013; Accepted Jun. 15, 2013; Revised Jul. 1, 2013
}

1992; Ho and Hoffman, 1993; Lincoln et al., 1995; Ge et al., 2013). In general, $G H$ binds to a $G H$ receptor and forms a dimer. Janus kinase and mitogen-activated protein kinase are involved in $G H$ activity (Herrington et al., 2000). Recently, studies of the $b G H$ gene have focused on single nucleotide polymorphisms (SNPs) within the gene and how the polymorphisms influence production traits such as milk production, growth, or carcass traits in cattle.

Roth et al. (1990) found a SNP in the $b G H$ promoter region, '253' SNP near the binding site of polyoma virus enhancer A binding protein 3 (PEA3) transcription factor. Theill and Karin (1993) identified '303' SNP in the first nucleotide of biding site of another transcription factor, thyroid hormone response element (TRE). The 303 SNP was confirmed in eight cattle breeds (Hecht and Geldermann, 1996). Ge et al. (2013) analyzed effects of the $b G H$ SNPs on growth traits and concentrations of $I G F-I$ in Angus, but did not find significant evidence that the SNPs were associated with the traits. However, Kim et al. (2004) reported a $b G H$ SNP, '- 120 ' SNP in promoter region of the gene, which was associated with 3-month weight and carcass weight in Hanwoo.

There are also many reports that $b G H$ SNPs, especially 
ones in exon 5, influenced milk production in Holstein and economically important traits in beef cattle (Eppard et al., 1992; Zhang et al., 1992, 1993; Lee et al., 1993; Lucy et al., 1993; Schlee et al., 1994; Yao et al., 1996). The $2141 \mathrm{C}>\mathrm{G}$ SNP encoding the $127^{\text {th }}$ amino acid of $b G H$ involves a change from leucine (CTG) to valine (GTG) (Zhang et al., 1992, 1993; Lucy et al., 1993). For the SNP, Eppard et al. (1992) found that the GTG increased milk yields in Holstein. However, Lee et al. (1993) and Lucy et al. (1993) reported that the mutation to valine decreased milk yield in cattle. Schlee et al. (1994) demonstrated that German black and white bulls with homozygous leucine had higher plasma levels than the ones with heterozygous leucine. Yao et al. (1996) reported that the $2291 \mathrm{~A}>\mathrm{C} b G H$ SNP was significantly associated with milk yield, fat, and protein content in Holstein cattle. Recently, Ardiyanti et al. (2012) reported association of bGH to fatty acid components in Japanese black cattle.

Yoon et al. (2003) found a $2258 \mathrm{C}>\mathrm{T}$ SNP of $b G H$ in Hanwoo, causing replacement of arginine (CGG) with tryptophan (TGG). Chikuni et al. (1994) also reported a 2277 C>T SNP in $b G H$ in Japanese cattle.

The objective of this study was to find any association of $b G H$ SNPs with growth and carcass traits in Hanwoo.

\section{MATERIALS AND METHODS}

\section{Animals and phenotype data}

A sample of 242 Hanwoo steers from 25 sires was collected from the Korea Animal Improvement Association. All the steers were under the progeny-testing program to select Hanwoo proven sires in the National Livestock Research Institute (NLRI), Korea. The steers were raised under tightly controlled conditions of the feeding program in the Daekwanryeong and Namwon branches of NLRI. The animals were born between the spring of 1998 and the fall of 2002, castrated at 6 months of age, and raised in groups of four animals per pen $(4 \mathrm{~m} \times 8 \mathrm{~m})$. After 6 months of age, the steers were fed concentrates consisting of $15 \%$ crude protein $(\mathrm{CP}) / 71 \%$ totally digestible nutrients (TDN) for a period of 60 to $90 \mathrm{~d}, 15 \% \mathrm{CP} / 71 \% \mathrm{TDN}$ for a period of $180 \mathrm{~d}$, and $13 \% \mathrm{CP} / 72 \%$ TDN for a period of 90 to $120 \mathrm{~d}$. The steers had access to roughage and fresh water ad libitum throughout the entire period. All steers were slaughtered approximately at 24 months of age. Live weight of each steer was measured before slaughter using electronic scales. Following a 24-h chilling, cold carcass weight was also measured.

Growth traits included weights of six-month (WT6), 12month (WT12), 18-month (WT18), and 24-month (WT24) of age. Average daily gain (ADG) was also measured. Carcass quality traits included carcass weight (CWT), backfat thickness (BF), longissimus dorsi (eye) muscle area
(EMA), and marbling scores (MS). According to the protocols of Korean Animal Product Grade System of Korean Institute for Animal Products Quality Evaluation, BF (mm) was measured at the $2 / 3$ point of backfat that was located toward abdomen along the right side of the eye muscle cross-section. EMA $\left(\mathrm{cm}^{2}\right)$ was measured in the eye muscle cross-section. MS was scored on a scale of 1 thorough 9 ( 1 = trace, $9=$ very abundant $)$ according to the Korean Beef Marbling Standard.

\section{Sequence analysis of $\boldsymbol{b} G \boldsymbol{H}$ gene}

Genomic DNA was extracted from white blood cells of 21 unrelated Hanwoo individuals using the phenolchloroform method (Sambrook et al., 2001). We sequenced $47 \mathrm{bp}$ to $2,528 \mathrm{bp}$ of the $b G H$ gene (GenBank accession number, M57764) and the flanking regions to evaluate SNP variants using the BigDye Terminator (ver. 3.1) cycle sequencing kit (Applied Biosystems, Foster City, CA) with an ABI 3730XL DNA analyzer (Applied Biosystems). Six primer sets for amplification and sequencing analysis were designed based on the GenBank sequence using Primer3 software. Primer sequences are shown in Table 1. Sequence editing was performed by visual confirmation using Sequencher 4.6 software (Gene Codes Corp., Ann Arbor, MI).

\section{Genotyping by single-base extension (SBE)}

A primer set (GH-P1-F and GH1-P1-R) was designed to generate a 639-bp product that included four SNPs in the $b G H$ gene promoter. Another primer set (GH-E1-F and GHE1-R) was designed to generate a 328-bp product that included 679-bp SNP in the exon 1 region. A third primer set (GH-E2-F and GH-E2-R) was designed to produce a 536-bp amplicon that included 1,692-bp SNP in intron 3, while a primer set (GH-E3-F and GH-E3-R) was designed to obtain a 428-bp product that included four SNPs in exon 4 (Table 1). Primer extension was performed using a SNaPshot ddNTP Primer Extension Kit (Applied Biosystems, Foster City, CA). To purify the primer extension products, exonuclease 1 and shrimp alkaline phosphatase were added to the reaction mixtures. The samples were incubated at $37^{\circ} \mathrm{C}$ for $1 \mathrm{~h}$ and the reactions were stopped by incubating at $72^{\circ} \mathrm{C}$ for $15 \mathrm{~min}$. The products were mixed with a Genescan 120 LIZ standard and HiDi formamide (Applied Biosystems) before being denatured at $95^{\circ} \mathrm{C}$ for $5 \mathrm{~min}$. Electrophoresis was performed using an ABI PRISM 3130XL Genetic Analyzer and the results were analyzed using GeneMapper v.4.0 software (Applied Biosystems).

\section{Statistical analysis}

Heterozygosity, minor allele frequency (MAF), and Hardy-Weinberg equilibrium (HWE) were assessed using 
Table 1. Sequences of primers for sequencing the bovine growth hormone $(b G H)$ gene in Hanwoo

\begin{tabular}{|c|c|c|c|c|c|c|c|}
\hline & Primer $n$ & & $\begin{array}{c}\text { Primer } \\
\text { size (bp) }\end{array}$ & Primer sequence & Location & $\begin{array}{l}\text { Fragment } \\
\text { size (bp) }\end{array}$ & $\begin{array}{l}\text { Annealing } \\
\text { temp }\left({ }^{\circ} \mathrm{C}\right)\end{array}$ \\
\hline \multirow[t]{12}{*}{ Sequencing } & GH1-N1 & $\mathrm{F}$ & 20 & CCAGGGATTGAACCTGAGTC & $47-558$ & 512 & 56 \\
\hline & & $\mathrm{R}$ & 21 & CCATTAGCACAGGCTGCCAGT & & & 56 \\
\hline & GH1-N2 & $\mathrm{F}$ & 20 & AGTGGAGACGGGATGATGAC & $451-972$ & 522 & 56 \\
\hline & & $\mathrm{R}$ & 21 & ССTCCTGGTCTCTCCCTAGGC & & & 56 \\
\hline & GH1-N3 & $\mathrm{F}$ & 21 & CATTTGGCCAAGTTTGAAATG & $852-1,413$ & 562 & 56 \\
\hline & & $\mathrm{R}$ & 20 & CATCCAGAACACCCAGGTTG & & & 56 \\
\hline & GH1-N4 & $\mathrm{F}$ & 18 & AACCGCGCACCAGCTTAG & $1,314-1,839$ & 526 & 56 \\
\hline & & $\mathrm{R}$ & 20 & GAGAAGCTGAAGGACCTGGA & & & 56 \\
\hline & GH1-N5 & $\mathrm{F}$ & 20 & TCTCACTGCTCCTCATCCAG & $1,722-2,186$ & 465 & 56 \\
\hline & & $\mathrm{R}$ & 20 & GCAGATCCTCAAGCAGACCT & & & 56 \\
\hline & GH1-N6 & $\mathrm{F}$ & 20 & CTTCGGCCTCTCTGTCTCTC & $2,105-2,528$ & 424 & 56 \\
\hline & & $\mathrm{R}$ & 21 & GAAGACAATAGCAGGCATGCT & & & 56 \\
\hline \multirow[t]{8}{*}{ Genotyping } & GH1-P1 & $\mathrm{F}$ & 20 & CCAGGGATTGAACCTGAGTC & & 639 & 62 \\
\hline & & $\mathrm{R}$ & 20 & TGAGTCGTCTGGTGAACTGG & & & 62 \\
\hline & GH1-E1 & $\mathrm{F}$ & 20 & ACGGGAACAGGATGAGTGAG & & 328 & 58 \\
\hline & & $\mathrm{R}$ & 20 & CACATTCGGAAGCCCTAAAG & & & 58 \\
\hline & GH1-E2 & $\mathrm{F}$ & 20 & CAGGTTGCCTTCTGCTTCTC & & 536 & 58 \\
\hline & & $\mathrm{R}$ & 20 & CGTGCATTCTCCTGGCTAAG & & & 58 \\
\hline & GH1-E3 & $\mathrm{F}$ & 20 & TTTTCСССТTTTGAAACCTC & & 428 & 54 \\
\hline & & $\mathrm{R}$ & 20 & CGATGCAATTTCCTCATTTT & & & 54 \\
\hline
\end{tabular}

Haploviewer v4.2 (Barret et al., 2005). HWE was tested by comparing the expected and observed genotype frequencies using a chi-square test. Associations of growth and carcass traits for each SNP were analyzed with a mixed analysis of covariance (ANCOVA) linear model using SAS v9.1 (SAS Institute, Cary, NC). For growth traits, two fixed effect were fitted, year-season-birth place and SNP genotype. For carcass quality traits, an additional effect was included in the model, a covariate for age in days at the time of slaughter.

\section{RESULTS AND DISCUSSION}

The DNA segment of 2,482 bps that was located at 47 to 2,528 bp of $b G H$ gene was sequenced, and a total of 10 SNPs were identified (Figure 1 and Table 2). Among the ten
SNPs, four SNPs were located in the promoter region, i.e. $253 \mathrm{C}>\mathrm{T}, 303 \mathrm{C}>\mathrm{T}, 502 \mathrm{C}>\mathrm{T}$, and $559 \mathrm{G}>\mathrm{A}$. Results of association tests between the four SNPs and growth and carcass traits showed that $303 \mathrm{C}>\mathrm{T}$ and $559 \mathrm{G}>\mathrm{A}$ SNPs had significantly affected WT6 and eye muscle area (EMA), respectively at $p=0.05$ level (Tables 3 and 4). The significant SNPs in the $b G H$ gene promoter region may have limited efficiency as molecular markers, partly because the SNPs are located in the SINE/BovA2 repeat element, in which repetitive mutations occur frequently (Vaccarelli et al., 2008), suggesting that the SNPs does not strongly influence gene expression. Alternatively, the SNPs may affect growth and carcass traits due to great linkage disequilibrium with the causal variants that were closely located to the $b G H$ SNPs (Ge et al., 2013). Kim et al. (2004) reported that a SNP at a promoter position -120

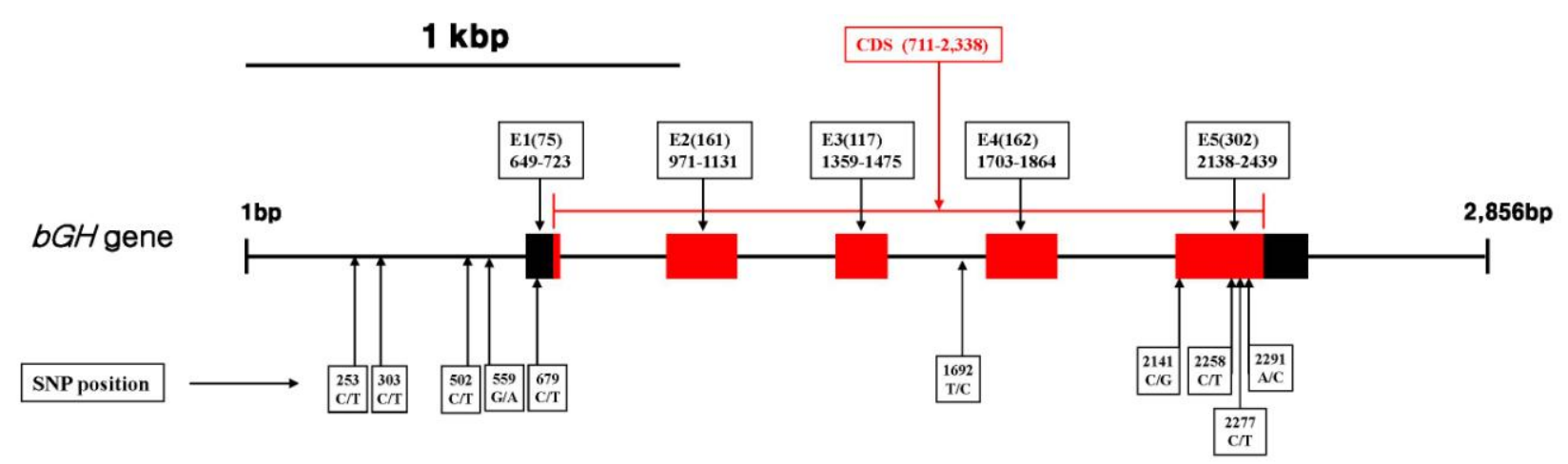

Figure 1. Position of SNPs in the bovine growth hormone $(b G H)$ gene in Hanwoo. 
Table 2. Genotype and allele frequencies of SNPs within the $b G H$ gene of Hanwoo

\begin{tabular}{|c|c|c|c|c|c|c|c|c|}
\hline SNP & Position & & $\begin{array}{l}\text { e allele } \mathrm{fr} \\
\text { of individ }\end{array}$ & & $\begin{array}{c}\text { No. of } \\
\text { individuals }\end{array}$ & $\mathrm{MAF}^{1}$ & $\mathrm{H}^{2}$ & $\mathrm{HWE}^{3}$ \\
\hline $253 \mathrm{C}>\mathrm{T}$ & Promoter & $\begin{array}{c}\mathrm{CC}(131) \\
0.557\end{array}$ & $\begin{array}{l}\mathrm{CT}(82) \\
0.349\end{array}$ & $\begin{array}{l}\text { TT(22) } \\
0.094\end{array}$ & 235 & 0.268 & 0.392 & 0.089 \\
\hline $303 \mathrm{C}>\mathrm{T}$ & Promoter & $\begin{array}{c}\mathrm{CC}(202) \\
0.860\end{array}$ & $\begin{array}{l}\mathrm{CT}(28) \\
0.119\end{array}$ & $\begin{array}{l}\mathrm{TT}(5) \\
0.021\end{array}$ & 235 & 0.081 & 0.149 & 0.002 \\
\hline $502 \mathrm{C}>\mathrm{T}$ & Promoter & $\begin{array}{c}\mathrm{CC}(152) \\
0.647\end{array}$ & $\begin{array}{l}\mathrm{CT}(74) \\
0.315\end{array}$ & $\begin{array}{l}\mathrm{TT}(9) \\
0.038\end{array}$ & 235 & 0.196 & 0.315 & 0.999 \\
\hline $559 \mathrm{G}>\mathrm{A}$ & Promoter & $\begin{array}{c}\mathrm{GG}(231) \\
0.983\end{array}$ & $\begin{array}{l}\mathrm{GA}(4) \\
0.017\end{array}$ & $\begin{array}{l}\mathrm{AA}(0) \\
0.000\end{array}$ & 235 & 0.009 & 0.017 & 0.895 \\
\hline $679 \mathrm{C}>\mathrm{T}$ & Exon1 & $\begin{array}{c}\mathrm{CC}(225) \\
0.978\end{array}$ & $\begin{array}{l}\mathrm{CT}(5) \\
0.022\end{array}$ & $\begin{array}{l}\mathrm{TT}(0) \\
0.000\end{array}$ & 230 & 0.011 & 0.022 & 0.868 \\
\hline $1692 \mathrm{~T}>\mathrm{C}$ & Intron3 & $\begin{array}{l}\mathrm{CC}(5) \\
0.024\end{array}$ & $\begin{array}{l}\mathrm{CT}(56) \\
0.269\end{array}$ & $\begin{array}{c}\mathrm{TT}(147) \\
0.707\end{array}$ & 208 & 0.159 & 0.267 & 0.903 \\
\hline $2141 \mathrm{C}>\mathrm{G}$ & Exon5 & $\begin{array}{c}\mathrm{CC}(196) \\
0.848\end{array}$ & $\begin{array}{c}\mathrm{CG}(27) \\
0.117\end{array}$ & $\begin{array}{l}\mathrm{GG}(8) \\
0.035\end{array}$ & 231 & 0.093 & 0.169 & 0.000 \\
\hline $2258 \mathrm{C}>\mathrm{T}$ & Exon5 & $\begin{array}{c}\mathrm{CC}(192) \\
0.831\end{array}$ & $\begin{array}{l}\text { CT(39) } \\
0.169\end{array}$ & $\begin{array}{l}\mathrm{TT}(0) \\
0.000\end{array}$ & 231 & 0.084 & 0.155 & 0.161 \\
\hline $2277 \mathrm{C}>\mathrm{T}$ & Exon5 & $\begin{array}{c}\mathrm{CC}(222) \\
0.961\end{array}$ & $\begin{array}{l}\mathrm{CT}(9) \\
0.039\end{array}$ & $\begin{array}{l}\mathrm{TT}(0) \\
0.000\end{array}$ & 231 & 0.019 & 0.038 & 0.763 \\
\hline $2291 \mathrm{~A}>\mathrm{C}$ & Exon5 & $\begin{array}{l}\mathrm{CC}(10) \\
0.043\end{array}$ & $\begin{array}{l}\text { CA(67) } \\
0.290\end{array}$ & $\begin{array}{c}\mathrm{AA}(154) \\
0.667\end{array}$ & 231 & 0.188 & 0.306 & 0.436 \\
\hline
\end{tabular}

${ }^{1}$ Heterozygosity. ${ }^{2}$ Minor allele frequency. ${ }^{3} \mathrm{p}$ value indicates degree of deviation of genotype distribution from Hardy-Weinberg equilibrium.

spanning a DraI restriction site was associated with 3month weight and carcass weight in a Hanwoo population. However, our study did not confirm the SNP, partly because the SNP in Kim et al. (2004) was not detected with strong statistical evidence, i.e. comparison-wise $\mathrm{p}$ values were 0.025 and 0.041 for 3-month weight and carcass weight, respectively, which may be not confirmed in another random Hanwoo sample. Also, Kim et al. (2004) analyzed the association tests with estimated breeding values of the growth and carcass quality traits, while raw phenotypes were used in this study.

In this study, $679 \mathrm{C}>\mathrm{T}$ SNP was found in exon 1, 1692 $\mathrm{T}>\mathrm{C}$ SNP in intron 3, and four SNPs $(2141 \mathrm{C}>\mathrm{G}, 2258 \mathrm{C}>\mathrm{T}$, $2277 \mathrm{C}>\mathrm{T}$, and $2291 \mathrm{~A}>\mathrm{C}$ ) in exon 5 of the $b G H$ gene. Among the SNPs in the CDS region, the $2141 \mathrm{C}>\mathrm{G}$, the $2258 \mathrm{C}>\mathrm{T}$, and the $2277 \mathrm{C}>\mathrm{T}$ SNPs were non-synonymous causing amino acid substitution, while the $2291 \mathrm{~A}>\mathrm{C}$ SNP was a silent mutation. Among the SNPs in exon 1 and intron 3, $679 \mathrm{C}>\mathrm{T}$ and $1692 \mathrm{~T}>\mathrm{C}$ did not significantly influence any growth or carcass trait (Tables 3 and 4). These results are in accordance with the report of Yao et al. (1996), in which there was no significant association of the SNPs with milk yield, fat and protein content in Holstein bulls.

The $2141 \mathrm{C}>\mathrm{G}$ SNP was non-synonymous and induced a mutation from leucine (CTG) to valine (GTG), which significantly affected ADG at $\mathrm{p}=0.05$ level (Table 3), even if HWE for the SNP was significantly deviated from expectation (Table 2). The $2258 \mathrm{C}>\mathrm{T}$ SNP was nonsynonymous, causing mutation of arginine to tryptophan in the process of transition from $\mathrm{C}$ to $\mathrm{T}$. The SNP significantly affected ADG and CWT at $\mathrm{p}=0.05$ level (Tables 3 and 4). The genotype effect of the 2258 SNP on ADG was 0.74 0.01 for $\mathrm{CC}$ and $0.71 \pm 0.01$ for CT, respectively (Table 3). For CWT, the estimates of CC and CT genotypes were $310.4 \pm 2.4$ and 298.5 \pm 4.9 , respectively (Table 4). For the SNP, Yoon et al. (2003) reported that MAF, Msp I (-), was low (0.00 to 0.054) in European Bos taurus species (Hereford, Angus, Charolais, Holstein, brown Swiss, Limousine, and Simmental), 0.043 to 0.229 in Asian Bos taurus breeds, except for Japanese black cattle (0.00), and 0.162 in Hanwoo. The MAF (C allele) of the 2258 SNP was 0.084 in this study (Table 4), which was lower than the frequency of the SNP in Yoon et al. (2003). This may be partly due to sampling effect, i.e. a small sample size $(\mathrm{N}=$ 242 ) in this study. For the $2258 \mathrm{C}>\mathrm{T}$ SNP, the high allele frequency of the favorable allele $(\mathrm{C})$ in both European and Asian Bos taurus breeds indicate that selection for genetic improvement of ADG and CWT has been processed for the SNP or near the chromosomal region of the SNP.

There are some limitations in this association study. First of all, the sample size was small $(\mathrm{N}=242)$, such that some significant SNPs for growth and carcass quality traits may not have been detected. Second, there may have been a chance of a false positive SNP, i.e. spurious SNPs with significant evidence that have no true effects on the tested traits. Some significant SNPs, e.g. the $303 \mathrm{C}>\mathrm{T}$ SNP for WT6 or the $2258 \mathrm{C}>\mathrm{T}$ SNP for CWT (Tables 3 and 4), had MAF less than 0.05 , for which efficiency of marker-assisted 
Table 3. Least square mean and standard error of genotype effects of $b G H$ gene for growth traits in Hanwoo

\begin{tabular}{|c|c|c|c|c|c|}
\hline \multirow{2}{*}{$\begin{array}{l}\text { SNP } \\
303 \mathrm{C}>\mathrm{T}\end{array}$} & \multirow[t]{2}{*}{ Traits (kg) } & \multicolumn{3}{|c|}{$\begin{array}{l}\text { Genotype means } \pm \text { standard errors } \\
\text { (No. of individuals) }\end{array}$} & \multirow[t]{2}{*}{ p-value } \\
\hline & & CC(202) & $\mathrm{CT}(28)$ & TT(5) & \\
\hline & WT6 & $168.51 \pm 1.77^{b}$ & $170.53 \pm 4.68^{b}$ & $137.81 \pm 11.01^{\mathrm{a}}$ & 0.019 \\
\hline & WT12 & $277.35 \pm 2.27$ & $284.18 \pm 5.985$ & $261.69 \pm 14.07$ & 0.275 \\
\hline & WT18 & $411.72 \pm 2.98$ & $428.40 \pm 7.855$ & $404.56 \pm 18.46$ & 0.114 \\
\hline & WT24 & $564.35 \pm 4.03$ & $577.10 \pm 10.64$ & $594.13 \pm 25.00$ & 0.284 \\
\hline & $\mathrm{ADG}$ & $0.73 \pm 0.01$ & $0.75 \pm 0.02$ & $0.81 \pm 0.04$ & 0.062 \\
\hline \multirow[t]{6}{*}{$2141 \mathrm{C}>\mathrm{G}$} & & CC(196) & $\mathrm{CG}(27)$ & $\mathrm{GG}(8)$ & \\
\hline & WT6 & $168.02 \pm 1.78$ & $167.95 \pm 4.73$ & $149.54 \pm 8.55$ & 0.103 \\
\hline & WT12 & $276.60 \pm 2.34$ & $281.04 \pm 6.20$ & $276.18 \pm 11.21$ & 0.788 \\
\hline & WT18 & $410.86 \pm 3.09$ & $420.74 \pm 8.19$ & $418.93 \pm 14.80$ & 0.470 \\
\hline & WT24 & $562.55 \pm 4.13$ & $566.09 \pm 10.95$ & $596.31 \pm 19.79$ & 0.241 \\
\hline & $\mathrm{ADG}$ & $0.73 \pm 0.01^{\mathrm{a}}$ & $0.74 \pm 0.02^{\mathrm{a}}$ & $0.81 \pm 0.03^{\mathrm{b}}$ & 0.038 \\
\hline \multirow[t]{6}{*}{$2258 \mathrm{C}>\mathrm{T}$} & & CC(192) & CT(39) & $\mathrm{TT}(0)$ & \\
\hline & WT6 & $167.25 \pm 1.89$ & $168.46 \pm 3.84$ & & 0.779 \\
\hline & WT12 & $278.02 \pm 2.46$ & $273.14 \pm 4.99$ & & 0.381 \\
\hline & WT18 & $414.89 \pm 3.23$ & $400.85 \pm 6.56$ & & 0.057 \\
\hline & WT24 & $567.62 \pm 4.33$ & $548.59 \pm 8.79$ & & 0.054 \\
\hline & $\mathrm{ADG}$ & $0.74 \pm 0.01^{\mathrm{b}}$ & $0.71 \pm 0.01^{\mathrm{a}}$ & & 0.015 \\
\hline
\end{tabular}

${ }_{\mathrm{a}, \mathrm{b}}$ Mean values with different superscript letters within the same row are significantly different $(\mathrm{p}<0.05)$.

Table 4. Least square mean and standard error of genotype effects of $b G H$ gene for carcass quality traits in Hanwoo

\begin{tabular}{|c|c|c|c|c|c|}
\hline \multirow{2}{*}{$\frac{\mathrm{SNP}}{559 \mathrm{G}>\mathrm{A}}$} & \multirow[t]{2}{*}{ Traits } & \multicolumn{3}{|c|}{$\begin{array}{l}\text { Genotype means } \pm \text { standard errors } \\
\text { (No. of individuals) }\end{array}$} & \multirow[t]{2}{*}{ p-value } \\
\hline & & GG(231) & GA(4) & $\mathrm{AA}(0)$ & \\
\hline \multirow{9}{*}{$2258 \mathrm{C}>\mathrm{T}$} & CWT (kg) & $309.62 \pm 2.18$ & $296.37 \pm 15.44$ & & 0.397 \\
\hline & $\operatorname{LMA}\left(\mathrm{cm}^{2}\right)$ & $76.17 \pm 0.55^{b}$ & $67.89 \pm 3.89^{a}$ & & 0.037 \\
\hline & $\mathrm{BF}(\mathrm{mm})$ & $7.10 \pm 0.19$ & $7.80 \pm 1.36$ & & 0.614 \\
\hline & MS & $5.82 \pm 0.23$ & $3.89 \pm 1.65$ & & 0.249 \\
\hline & & $\mathrm{CC}(192)$ & CT(39) & $\mathrm{TT}(0)$ & \\
\hline & CWT (kg) & $310.41 \pm 2.41^{b}$ & $298.50 \pm 4.93^{a}$ & & 0.031 \\
\hline & $\operatorname{LMA}\left(\mathrm{cm}^{2}\right)$ & $76.11 \pm 0.61$ & $74.93 \pm 1.24$ & & 0.392 \\
\hline & $\mathrm{BF}(\mathrm{mm})$ & $6.97 \pm 0.21$ & $7.40 \pm 0.44$ & & 0.375 \\
\hline & MS & $5.79 \pm 0.27$ & $5.48 \pm 0.54$ & & 0.615 \\
\hline
\end{tabular}

${ }^{\mathrm{a}, \mathrm{b}}$ Mean values with different superscript letters within the same row are significantly different $(\mathrm{p}<0.05)$.

selection would not be high.

Our results indicate that four SNPs in the $b G H$ gene were associated with growth and carcass quality traits in Hanwoo (Tables 3 and 4). However, further study is needed to validate effects of the significant SNPs, before considering implementation of marker-assisted selection in Hanwoo commercial populations.

\section{ACKNOWLEDGEMENTS}

This research was supported by a grant titled as "Development of production technologies for high quality $\&$ nutrional values of beef in Hanwoo from the Technology Development Program for Agriculture and Forestry (Project
No. 311016-3), Ministry of Agriculture, Forestry, and Fisheries, Republic of Korea. Jong-Joo Kim's work was also supported by the Yeungnam University Research Grant 2012.

\section{REFERENCES}

Ardiyanti, A., T. Abe, N. Tameoka, E. Kobayashi, N. Shoji, Y. Ohtani, K. Suzuki, S. Roh, and K. Katoh. 2012. Effects of growth hormone gene polymorphism on lipogenic gene expression levels in diaphragm tissues of Japanese black heifers. Asian-Aust. J. Anim. Sci. 25:1055-1062.

Chikuni, K., T. Nagatsuma, T. Tabata, M. Monma, M. Saito, S. Ozawa, and K. Ozutsumi. 1994. Genetic variants of the growth hormone gene in Japanese cattle. Anim. Sci. Technol. (Jpn.) 
65:340-346.

Choi, Y. J., D. S. Yim, J. S. Cho, B. D. Cho, K. J. Na, and M. G. Baik. 1997. Analysis of restriction fragment length polymorphism in the bovine growth hormone gene related to growth performance and carcass quality of Korean native cattle. Meat. Sci. 45:405- 410

Eppard, P. J., L. A. Nenthe, B. N. Violan, S. Ganguli, R. L. Hintz, L. Kung Jr., G. G. Krivi, and G. M. Lanza. 1992. Comparison of the galactopoietic response to pituitary-derived and recombinant-derived variants of bovine growth hormone. J. Endocrinol. 132:47-56.

Ferraz, A. L., J. C. Bortolossi, R. A. Curi, M. I. T. Ferro, J. A. Ferro, and L. R. Furlan. 2006. Identification and characterization of polymorphisms within the 5' flanking region, first exon and part of first intron of bovine $G H$ gene. J. Anim. Breed. Genet. 123:208-212.

Ge, W., M. E. Davis, H. C. Hines, K. M. Irvin, and R. C. Simmen. 2003. Association of single nucleotide polymorphisms in the growth hormone and growth hormone receptor genes with blood serum insulin-like growth factor I concentration and growth traits in Angus cattle. J. Anim. Sci. 81:641-648.

Gordon, D. F., D. P. Quick, C. R. Erwin, J. E. Donelson, and R. A. Maurer. 1983. Nucleotide sequence of the bovine growth hormone chromosomal gene. Mol. Cell. Endocrinol. 33:81-95.

Hecht, C. and H. Geldermann. 1996. Variants within the 5'flanking region and intron I of the bovine growth hormone gene. Anim. Genet. 27:329-332.

Hediger, R., S. E. Johnson, W. Barendse, R. D. Drinkwater, S. S. Moore, and J. Hetzel. 1990. Assignment of the growth hormone gene locus to 19q26-qter in cattle and to 11q25-qter in sheep by in situ hybridization. Genomics 8:171-174.

Herrington, J., L., S. Smit, J. Schwartz, and C. Carter-Su. 2000. The role of STAT proteins in growth hormone signaling. Oncogene.19:2585-97.

Ho, K. K. and D. M. Hoffman. 1993. Aging and growth hormone. Horm. Res. 40:80-86.

Kim, N. K., Y. W. Seo, G. H. Kim, J. H. Joh, O. H. Kim, E. R Chung, and C. S. Lee. 2004. A previously unreported DraI polymorphism within the regulatory region of the bovine growth hormone gene and its association with growth traits in Korean Hanwoo cattle. Anim. Genet. 35:152-154.

Lee, B. K., G. F. Lin, B. A. Crooker, M. P. Murtaugh, L. B. Hansen, and H. Chgester-Jones. 1996. Association of somatotropin (BST) gene polymorphism at the 5th exon with selection for milk yield in Holstein cows. Domest. Anim. Endocrinol. 13:373-381

Lincoln, D. T., F. Sinowatz, E. El-Hifnawi, R. L. Hughes, and M. Waters. 1995. Evidence of a direct role for growth hormone $(\mathrm{GH})$ in mammary gland proliferation and lactation. Anat. Histol. Embryol. 24:107-115.

Lucy, M. C., S. D. Hauser, P. J. Eppard, G. G. Krivi, J. H. Clark, D. E. Bauman, and R. J. Collier. 1993. Variants of somatotropin in cattle: gene frequencies in major dairy breeds and associated milk production. Domest. Anim. Endocrinol. 10:325-333.
Miller, W. L., J. A. Martial, and J. D. Baxter. 1980. Molecular cloning of DNA complementary to bovine growth hormone mRNA. J. Biol. Chem. 255:7521-7524.

Roth, P., C. Nerlov, R. Blasi, and M. Johnsen. 1990. Transcription factor PEA3 participates in the induction of urokinase plasminogen activator transcription in murine kerainocytes stimulated with epidermal growth factor or phorbolester. Nucl. Acid. Res. 18:5009-5017.

Sambrook, J. and D. W. Russell. 2001. Molecular cloning: A laboratory manual. Vol. $13^{\text {rd }}$ ed.: Cold Spring Harbor. New York. pp. 6.4-6.12.

Santome, J. A., J. M. Dellacha, A. C. Paladini, C. E. Wolfenstein, C. Pena, E. Poskus, S. T. Daurat, M. J. Biscoglio, Z. M. De Sese, and A. V. De Sanguesa. 1971. The amino acid sequence of bovine growth hormone. FEBS Lett. 16:198-200.

Schlee, P., R. Graml, E. Schallenberger, D. Schams, O. Rottmann, A. Olbrich-Bludau, and F. Pirchner. 1994. Growth hormone and insulin-like growth factor I concentrations in bulls of various growth hormone genotypes. Theor. Appl. Genet. $88: 497-500$.

Sumantran, V. N., M. L. Tsai, and J. Schwartz. 1992. Growth hormone induces $c$-fos and $c$-jun expression in cells with varying requirements for differentiation. Endocrinology 130: 2016-2024

Theill, L. E. and M. Karin. 1993. Transcriptional control of $G H$ expression and anterior pituitary development. Endocrine Rev. 14:670-689.

Vaccarelli, G., C. M. Maria, A. Rachele, P. Graziano, and C. Salvatrice. 2008. Genomic organization and recombinational unit duplication-driven evolution of ovine and bovine $\mathrm{T}$ cell receptor gamma loci. BMC Genomic 9:81.

Wallis, M. 1973. The primary structure of bovine growth hormone. FEBS Lett. 35:11-14.

Woychik, R. P., S. A. Camper, R. H. Lyons, S. Horowitz, E. C. Goodwin, and F. M. Rottman. 1982. Cloning and nucleotide sequencing of the bovine growth hormone gene. Nucl. Acid. Res. 10:7197-7210.

Yao, J., S. E. Aggrey, D. Zadworny, J. F. Hayes, and U. Kuhnlein. 1996. Sequence variations in the bovine growth hormone gene characterized by single-strand conformation polymorphism (SSCP) analysis and their association with milk production traits in Holsteins. Genetics 144:1809-1816.

Yoon, D. H., T. H. Kim, K. H. Lee, E. W. Park, H. K. Lee, I. C. Cheong, and K. C. Hong. 2003. A missense mutation in exon 5 of the bovine growth hormone gene. J. Anim. Sci. Technol. (Kor.) 45:13-22

Zhang, H. M., D. R. Brown, S. K. Denise, and R. L. Ax. 1992. Nucleotide sequence determination of a bovine somatotropin allele. Anim. Genet. 23:578.

Zhang, H. M., K. C. Maddock, D. R. Browns, S. K. Denise, and R. L. Ax. 1993. Bovine growth hormone gene frequencies in samples of U.S. AI bulls (Abstr.). J. Anim. Sci. 71:93. 